\title{
Tetracoordinated bis-phenanthroline Copper- complex couple as efficient redox mediators for dye solar cells
}

Mirko Magni, ${ }^{\dagger,}{ }^{*}$ Roberto Giannuzzi, ${ }^{*}$ Alessia Colombo, ${ }^{\dagger *}$ Maria Pia Cipolla, ${ }^{*}$ Claudia Dragonetti, ${ }^{\dagger}$ Stefano Caramori, ${ }^{*}$ Stefano Carli, ${ }^{*}$ Roberto Grisorio, ${ }^{*}$ Gian Paolo Suranna, ${ }^{*}$ Carlo Alberto Bignozzi, ${ }^{*}$ Dominique Roberto ${ }^{\dagger}$ and Michele Manca $^{\not+*}$ *

${ }^{\dagger}$ Dip. di Chimica, Università di Milano, UdR dell’INSTM, Via Golgi, Milano, Italy.

$\ddagger$ CBN-Fondazione Istituto Italiano di Tecnologia, Via Barsanti, Arnesano (Lecce), Italy.

${ }^{¥}$ Dip. Scienze Chimiche e Farmaceutiche, Università di Ferrara, Via F. di Mortara, Ferrara, Italy.

+ Dip. di Ingegneria Civile, Ambientale, del Territorio, Edile e di Chimica, Politecnico di Bari, via Orabona, Bari and CNR-NANOTEC c/o Campus Ecotekne, via Monteroni, Lecce, Italy. 


\section{Synthesis of copper complexes}

\section{Synthesis of copper(I) complexes 1 and 3}

Copper complexes $\mathbf{1}$ and $\mathbf{3}$ were synthesized and characterized following a procedure reported in the literature, i.e. starting from $\mathrm{Cu}_{2} \mathrm{O}$, preparing the intermediate complex $\left[\mathrm{Cu}\left(\mathrm{CH}_{3} \mathrm{CN}\right)_{4}\right] \mathrm{PF}_{6}$, then adding two equivalents of the corresponding phenanthroline ligand in dry dichloromethane. The 2,9-dimethyl-1,10-phenanthroline is commercially available while the 2-mesityl-4,7-dimethyl-1,10phenanthroline was prepared by nucleophilic aromatic substitution of 4,7-dimethyl-1,10phenanthroline with mesityllithium as previously reported by some of us. ${ }^{1}$ Attention: preparation of mesityllithium involved employment of tert-butyllithium solution which must be handled with great care being highly inflammable in air. Suitable precautions and tools should be taken. The ${ }^{1} \mathrm{H}$ NMR spectra (see below), recorded at $400 \mathrm{MHz}(\mathrm{T}=300 \mathrm{~K})$ in $\mathrm{CD}_{3} \mathrm{CN}$ on a Bruker Avance-400 instrument, are in agreement with the literature. Chemical shifts $(\delta)$ for ${ }^{1} \mathrm{H}$ NMR spectra are expressed in ppm relative to internal $\mathrm{Me}_{4} \mathrm{Si}$ as standard. Signals were abbreviated as s, singlet; d, doublet. Crystals suitable for X-ray analysis grew only for complex $\mathbf{1}$ and its crystal structure was already published. ${ }^{1}$

2-mesityl-4,7-dimethyl-1,10-phenanthroline, ${ }^{1} \mathrm{H} \mathrm{NMR}\left(400 \mathrm{MHz}, \mathrm{CD}_{3} \mathrm{CN}\right) \delta(\mathrm{ppm}): 8.93(\mathrm{~d}, J=$ $4.2 \mathrm{~Hz}, 1 \mathrm{H}), 8.22(\mathrm{~d}, J=8.5 \mathrm{~Hz}, 1 \mathrm{H}), 8.18(\mathrm{~d}, J=8.5 \mathrm{~Hz}, 1 \mathrm{H}), 7.54(\mathrm{~d}, J=4.2 \mathrm{~Hz}, 1 \mathrm{H}), 7.48$ (s, 1H), $7.00(\mathrm{~s}, 2 \mathrm{H}), 2.85(\mathrm{~s}, 3 \mathrm{H}), 2.84(\mathrm{~s}, 3 \mathrm{H}), 2.36(\mathrm{~s}, 3 \mathrm{H}), 2.00(\mathrm{~s}, 6 \mathrm{H})$.

$\left.[\mathrm{Cu} \text { (2-mesityl-4,7-dimethyl-1,10-phenanthroline) })_{2}\right]\left[\mathrm{PF}_{\mathbf{6}}\right], \mathbf{1},{ }^{1} \mathrm{H} \mathrm{NMR}\left(400 \mathrm{MHz}, \mathrm{CD}_{3} \mathrm{CN}\right) \delta$ (ppm): $8.82(\mathrm{~d}, J=4.3 \mathrm{~Hz}, 2 \mathrm{H}), 8.28(\mathrm{~d}, J=8.5 \mathrm{~Hz}, 2 \mathrm{H}), 8.25(\mathrm{~d}, J=8.5 \mathrm{~Hz}, 2 \mathrm{H}), 7.68(\mathrm{~d}, J=4.3$ $\mathrm{Hz}, 2 \mathrm{H}), 7.41(\mathrm{~s}, 2 \mathrm{H}), 6.19(\mathrm{~s}, 2 \mathrm{H}), 5.81(\mathrm{~s}, 2 \mathrm{H}), 2.91(\mathrm{~s}, 6 \mathrm{H}), 2.85(\mathrm{~s}, 6 \mathrm{H}), 1.94(\mathrm{~s}, 6 \mathrm{H}), 1.68$ (s, $6 \mathrm{H}), 1.04(\mathrm{~s}, 6 \mathrm{H})$. 
2-mesityl-4,7-dimethyl-1,10-phenanthroline and [Cu(2-mesityl-4,7-dimethyl-1,10phenanthroline $\left.)_{2}\right]\left[\mathrm{PF}_{6}\right], 1,{ }^{1} \mathrm{H}$ NMR spectra.
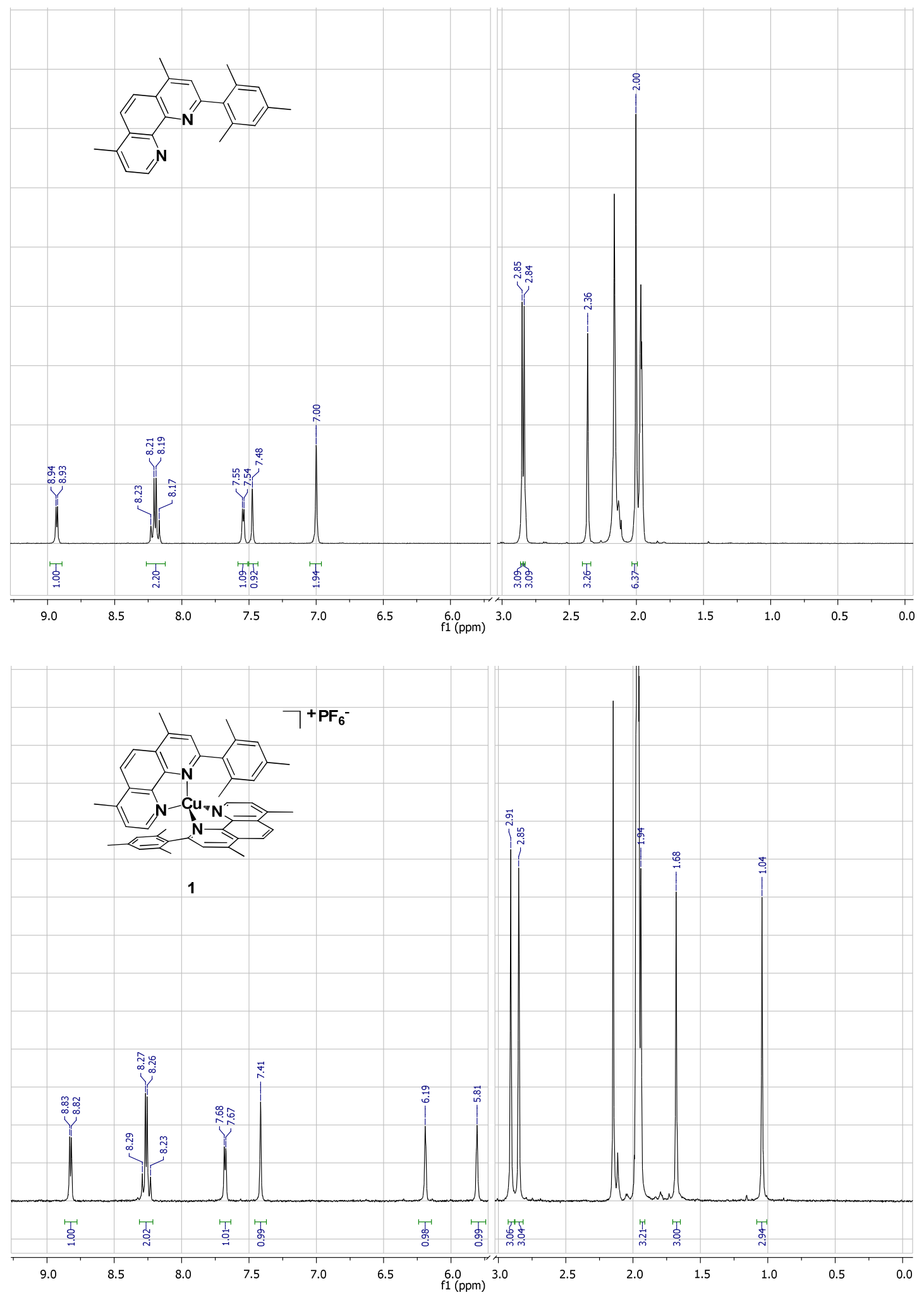
$\left[\mathbf{C u}(\text { 2,9-dimethyl-1,10-phenanthroline })_{2}\right]\left[\mathbf{P F}_{\mathbf{6}}\right], \mathbf{3},{ }^{1} \mathrm{H} \mathrm{NMR}\left(400 \mathrm{MHz}, \mathrm{CD}_{3} \mathrm{CN}\right) \delta(\mathrm{ppm}): 8.60(\mathrm{~d}$, $J=8.1 \mathrm{~Hz}, 4 \mathrm{H}), 8.11(\mathrm{~s}, 4 \mathrm{H}), 7.84(\mathrm{~d}, J=8.1 \mathrm{~Hz}, 4 \mathrm{H}), 2.43(\mathrm{~s}, 12 \mathrm{H})$.

\section{$\left[\mathrm{Cu}(2,9-\text { dimethyl-1,10-phenanthroline })_{2}\right]\left[\mathrm{PF}_{6}\right], 3,{ }^{1} \mathrm{H}$ NMR spectra.}

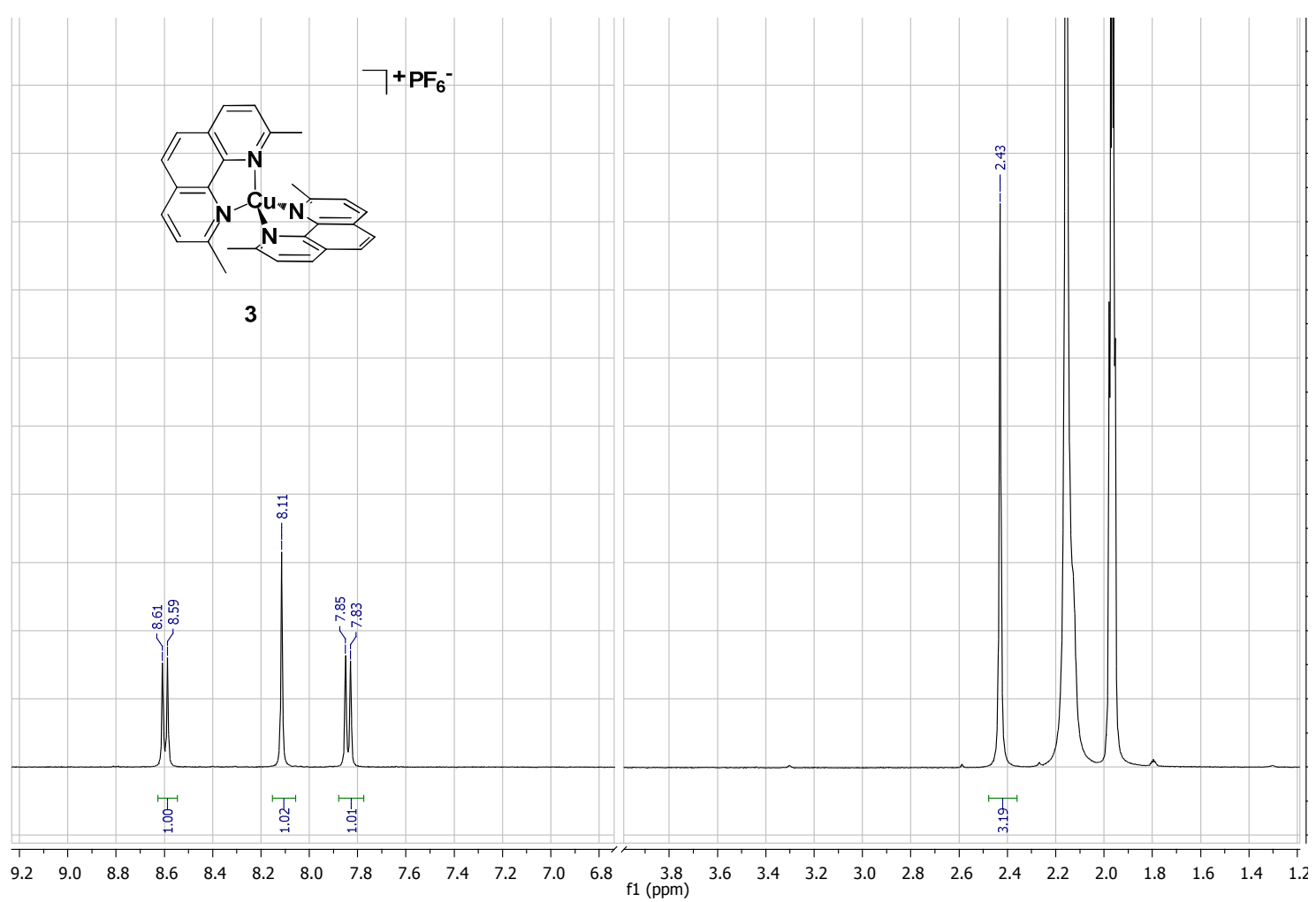

\section{Synthesis of [Cu(2,9-dimethyl-1,10-phenanthroline $\left.)_{2} C l\right]\left[P F_{6}\right], 4$}

The phenanthroline ligand $(0.46 \mathrm{mmol}, 97.5 \mathrm{mg})$ was dissolved in the minimum amount of EtOH $(15 \mathrm{~mL})$ and a solution of $\mathrm{CuCl}_{2} * 2 \mathrm{H}_{2} \mathrm{O}(0.23 \mathrm{mmol}, 39.2 \mathrm{mg})$ in $5 \mathrm{~mL}$ of EtOH was slowly added. The green mixture was stirred at room temperature for $30 \mathrm{~min}$ and then was diluted with $40 \mathrm{~mL}$ of water and a solution of $\mathrm{NaPF}_{6}(0.51 \mathrm{mmol}, 86.5 \mathrm{mg}$ in $2.6 \mathrm{~mL}$ of water $)$ was added. The resulting solution was stirred for $2 \mathrm{~h}$ and then the green precipitate was filtered, washed successively with water and diethylether and then dried at $55^{\circ} \mathrm{C}$ under reduced pressure. The product was obtained as a green solid in $40 \%$ yield. Attempts to collect crystals for X-ray structural analysis by slow evaporation of an acetone/ethanol solution or by layering $i-\operatorname{Pr}_{2} \mathrm{O}$ into an acetonitrile solution invariably failed. 
Elemental analysis: Calcd. for $\mathrm{C}_{28} \mathrm{H}_{24} \mathrm{ClCuF}_{6} \mathrm{~N}_{4} \mathrm{P}: \mathrm{C}, 50.92 ; \mathrm{H}, 3.66 ; \mathrm{N}, 8.48$; found: $\mathrm{C}, 50.71 ; \mathrm{H}$, 3.67; N, 8.52; $\mathrm{ESI}(+)$ FTICR MS(m/z) calcd. for $\left[\mathrm{C}_{28} \mathrm{H}_{24} \mathrm{ClCuN}_{4}\right]^{+} 514.0986$ found 514.0984 , and $479.1294\left[\mathrm{C}_{28} \mathrm{H}_{24} \mathrm{CuN}_{4}\right]^{2+}$.

\section{Details for PEDOT electrodeposition, dye solar cells characterization,}

\section{and transient absorption spectroscopy measurements}

\section{PEDOT-electrodeposition}

Films of poly(3,4-ethylendioxy)thiophene, PEDOT, employed for three-electrode measurements were electrodeposited on GC or Pt disk electrode in potentiodynamic conditions, cycling potential between 0 and $1.6 \mathrm{~V}$ vs SCE for 3-times in a $0.01 \mathrm{M}$ solution of the monomer in $\mathrm{ACN}$ with $\mathrm{LiClO}_{4}$ 0.1 M. The number of cycles were evaluated to make the CV peaks of complex 2 visible on the capacitive background of the film. PEDOT-coated electrode was then extracted, rinsed with ACN and cycled into a blank solution (ACN with $\left.\mathrm{LiClO}_{4} 0.1 \mathrm{M}\right)$ for at least 5 cycles, until two subsequent superimposable CV patterns were recorded. Finally the electrode was immersed into the test solution, containing $0.001 \mathrm{M}$ of complex 2 .

PEDOT-coated FTO cathodes for assembling in dye solar cells, DSCs, were obtained by electrooxidation of a $0.01 \mathrm{M}$ solution of EDOT monomer in $\mathrm{ACN}$ with $\mathrm{LiClO}_{4} 0.1 \mathrm{M}$ as supporting electrolyte through a three-step potentiostatic anodic deposition. Experimental conditions: $0.2 \mathrm{~V} v \mathrm{~s}$ SCE for $5 \mathrm{~s} ; 0.9 \mathrm{~V} v_{s} \mathrm{SCE}$ for $5 \mathrm{~s} ; 1.6 \mathrm{~V} v s \mathrm{SCE}$ for $30 \mathrm{~s}$. The polymer-modified FTOs were then carefully rinsed many times with pure acetonitrile, dried and stored in air before cell assembling.

\section{Dye solar cells characterization}

Photocurrent versus voltage, $i-E$, measurements were performed using a Keithley unit (Model 2400 Source Meter), while a Newport Sol3A Class AAA Solar Simulator (Model 94063A equipped with 
a $1000 \mathrm{~W}$ xenon arc lamp) served as a light source, scanning potential from $V_{\text {oc }}$ to short circuit conditions. The light intensity (or radiant power) was calibrated to $100 \mathrm{~mW} \mathrm{~cm}^{-2}$ using as reference a Silicon standard solar cell. Electrochemical analyses (on both DSCs and symmetrical cells) were performed using an Autolab PGSTAT 302N, and digitally processed using the NOVA 1.10 software. EIS spectra were recorded by sweeping the frequency from $50 \mathrm{kHz}$ to $0.01 \mathrm{~Hz}$, using 10 $\mathrm{mV}$ amplitude sine wave potential modulation superimposed to different bias potentials. EIS data were fitted to the equivalent circuit using the ZWiew ${ }^{\circledR}$ (Scribner Associates) software.

\section{Transient absorption spectroscopy measurements}

Excitation of the sensitized $\mathrm{TiO}_{2}$ films was carried out by using the $532 \mathrm{~nm}$ radiation generated by a Continuum Surelite (II) Nd-YAG laser, pumped at $1.26 \mathrm{kV}$. The excitation beam was defocused with a plano-concave lens and attenuated with a $25 \% \mathrm{~T}$ neutral density filter in order to achieve an energy density of $c a .2 \mathrm{~mJ} / \mathrm{cm}^{2} /$ pulse on the thin film, oriented at $45^{\circ}$ with respect to the laser beam. The white probe beam, generated by a pulsed $150 \mathrm{~W}$ Xe lamp was attenuated with a $380 \mathrm{~nm}$ cut-off filter and with a $50 \% \mathrm{~T}$ neutral density filter before passing through the sample and being focused on a 50 lines/mm grating of a triple grating Acton Monochromator. A $532 \mathrm{~nm}$ notch filter placed at the entrance of the monochromator prevented laser stray light to reach the phototube. $\Delta A$ traces were acquired on a Lecroy oscilloscope by using an input impedance of $350 \Omega$, and averaged over 30 laser shots at a frequency of $0.2 \mathrm{~Hz}$. 


\section{Electrochemical Characterization}

\section{Electrochemistry of complex 4:}

Analyzing the CV patterns of complex 4 recorded at different scan rate potentials, if the scan rate is sufficiently high (i.e. higher than $1 \mathrm{~V} \mathrm{~s}^{-1}$ ) an oxidation peak at less positive potential (peak A, in Fig. S1) is progressively visible, suggesting a complicated electrochemical process. The electrogenerated product, $4^{*}$, can be subject to a chemical step characterized by a kinetics accessible in $\mathrm{CV}$ timescale; so the reoxidation of the electro-generated product can occur through two different pathways corresponding to peak A and B in Fig. S1. At low scan rates the backward ET (peak B, Fig S1) occurs on a chemically-modified species different from $4^{*}$ corresponding, probably, to complex 3 resulting from the dissociation of $\mathrm{Cl}^{-}$ligand; the difference of geometries between reagent, $\mathbf{4}$, and product, $\mathbf{3}$, supports the aforementioned high electrochemical irreversibility of this ET. On the other hand at high scan rates (i.e. when the scan rate potential is comparable with the rate of the follow-up reaction) the electro-generated cuprous species can be (even partially) directly reoxidized without undergoing to ligand dissociation reaction, resulting in the more electrochemically reversible process (peak A, Fig. S1).

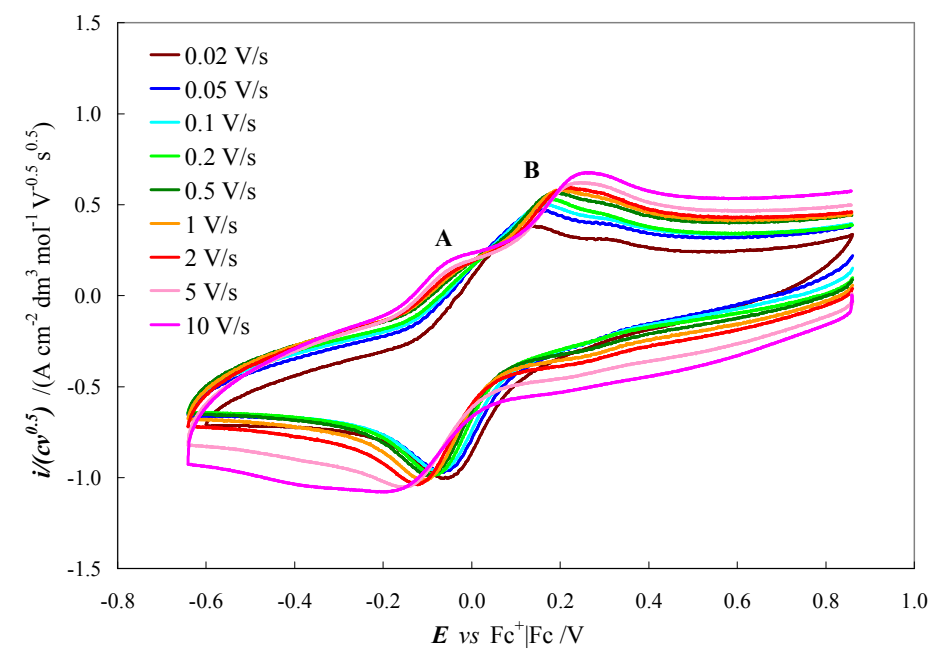

Figure S1 CVs recorded at increasing scan rate potentials for $0.001 \mathrm{M}$ complex 4 in ACN with $\mathrm{TBAPF}_{6} 0.1 \mathrm{M}$ on GC electrode. 
Addition of chloride ions to $\mathrm{Cu}(I)$-complex solutions:
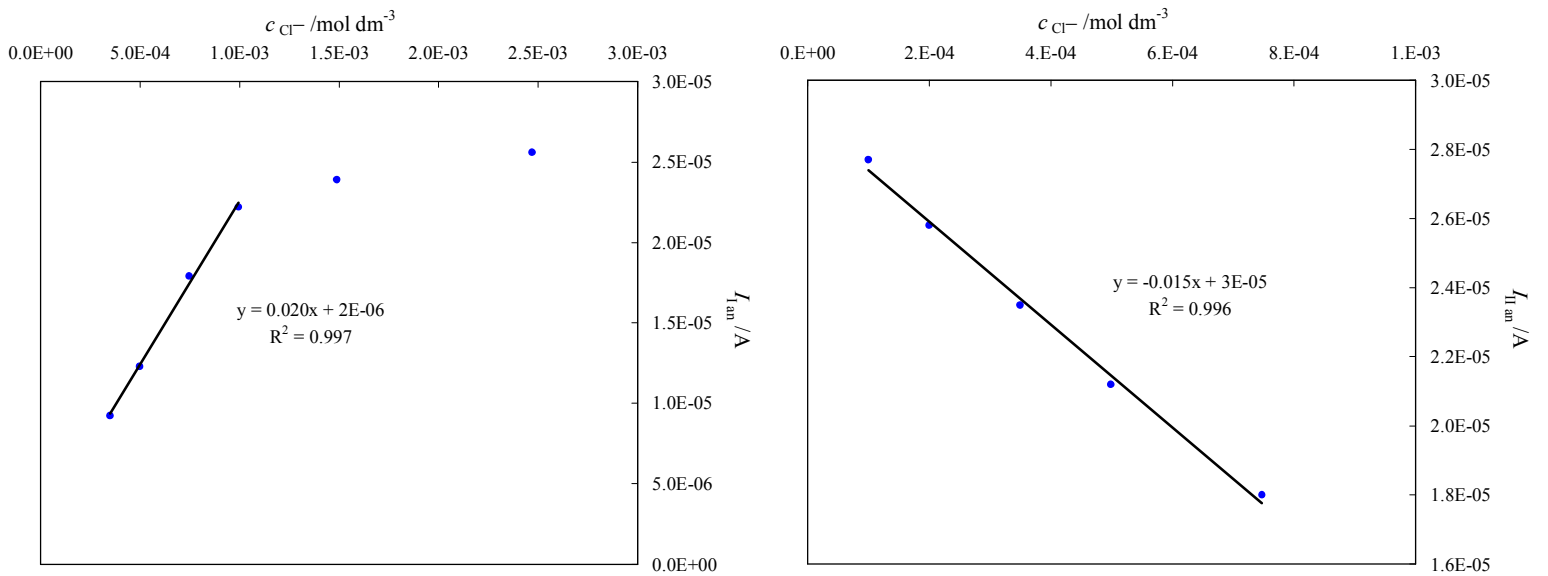

Figure S2 Increase (left) and decrease (right) of peak currents for the first (left) and second (right) oxidation peak of Figure 2 in the manuscript, at $0.2 \mathrm{~V}$ and $0.34 \mathrm{~V} v s \mathrm{Fc}^{+} \mid \mathrm{Fc}$ respectively, after subsequent additions of chloride ions to a solution of complex 3 in $\mathrm{ACN}$ with $\mathrm{TBAPF}_{6} 0.1 \mathrm{M}$. GC electrode; scan rate potential $0.2 \mathrm{~V} \mathrm{~s}^{-1}$.

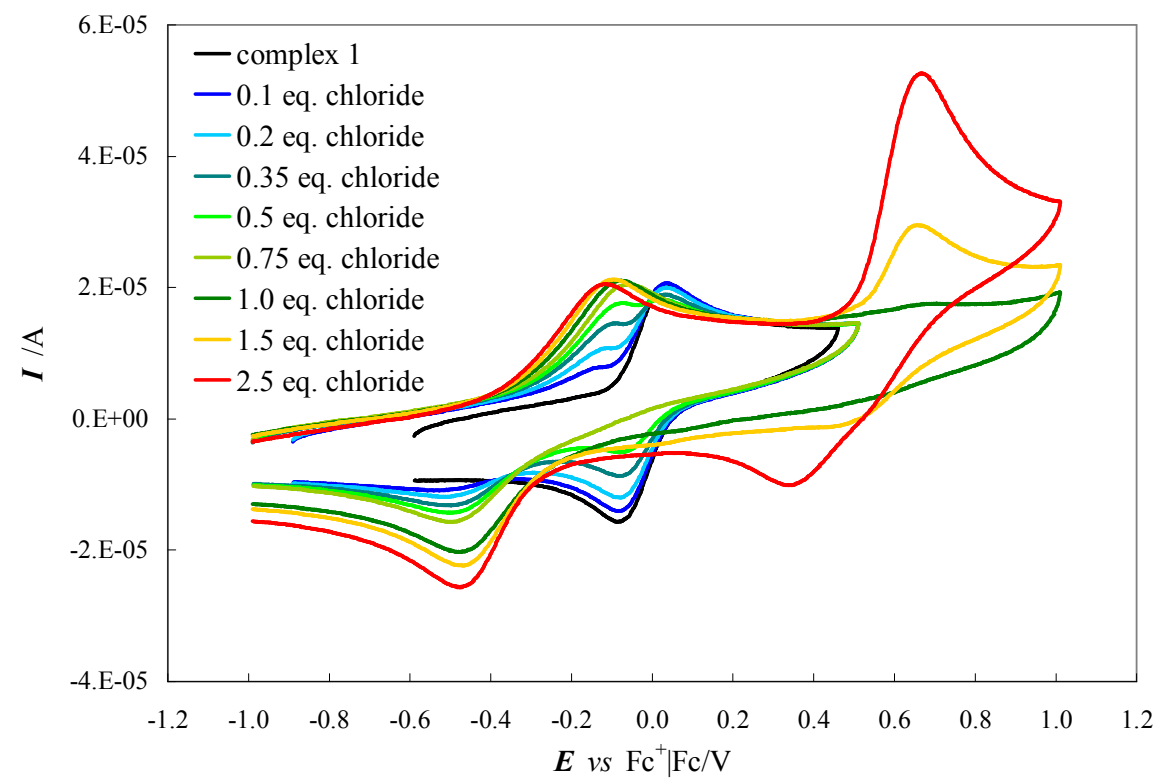

Figure S3. CVs of pristine complex 1 (black line) and with increasing amount of chloride ions (from 0.1 to 2.5 equivalents) spiked in the working medium as TBACl solution. Complex concentration $9.6 \cdot 10^{-4} \mathrm{M}$; ACN and $\mathrm{TBAPF}_{6} 0.1 \mathrm{M}$; GC electrode. 


\section{Effect of 4-tert-butylpyridine}

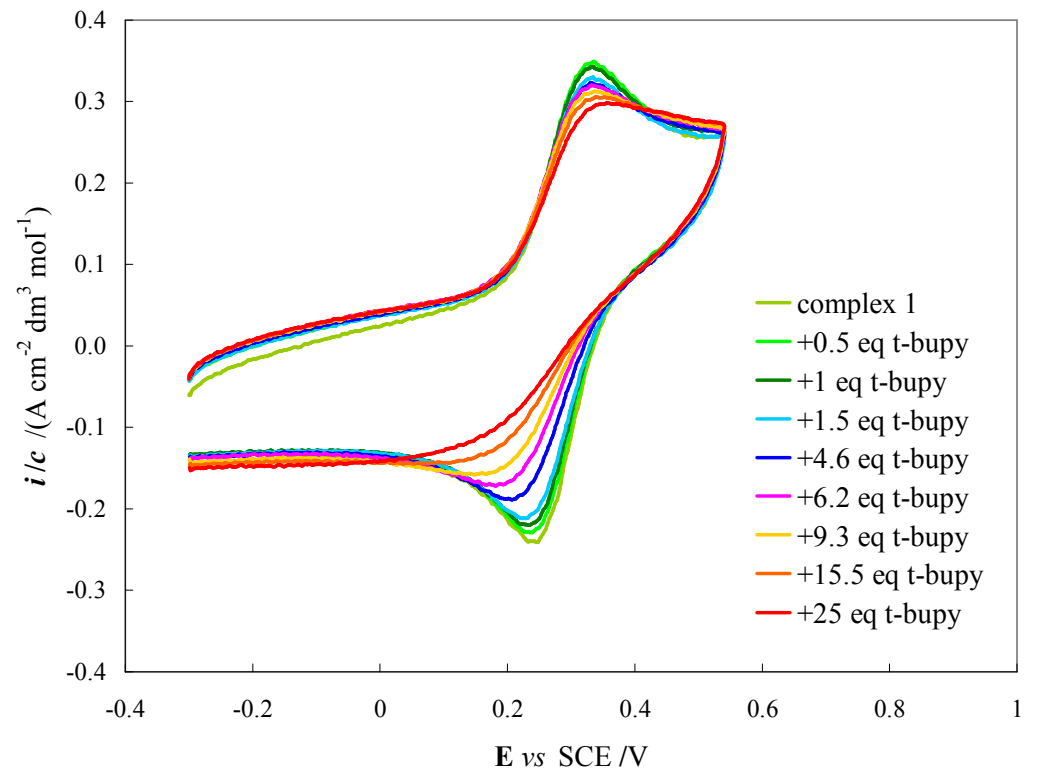

Figure S4. CVs for complex 1 in $\mathrm{ACN}$ with $\mathrm{LiClO}_{4} 0.1 \mathrm{M}$ after subsequent additions of 4-tertbutylpyridine, $t$-bpy, from substoichiometric quantity to a large excess (like that actually present in DSSC tests). GC electrode, potential scan rate $0.2 \mathrm{~V} \mathrm{~s}^{-1}$.
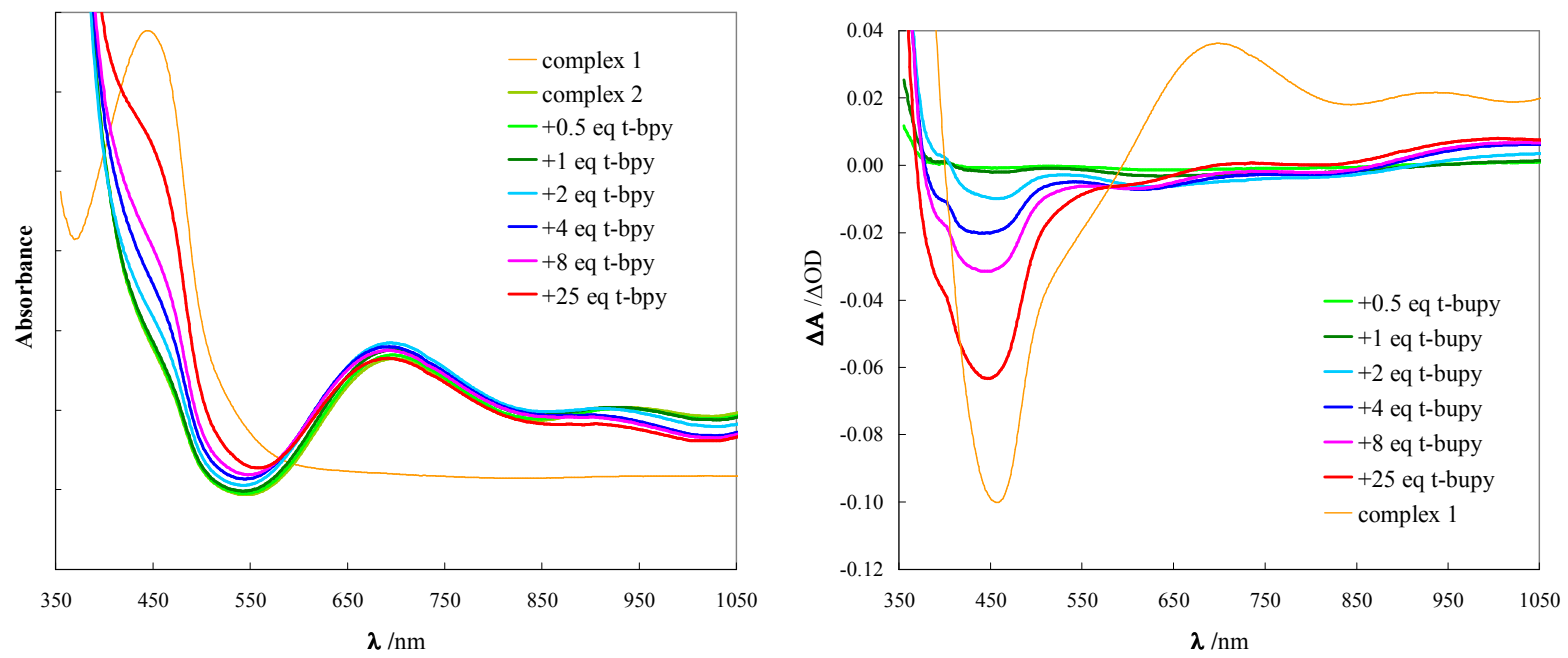

Figure S5 Electronic absorption spectra (left) and related differential patterns (right) of the complex $\mathbf{2}$ in $\mathrm{ACN}$ at increasing concentration of $t$-bpy. For sake of comparison the spectrum of complex $\mathbf{1}$ is also reported (orange thin line). 


\section{Electron transfer kinetics}
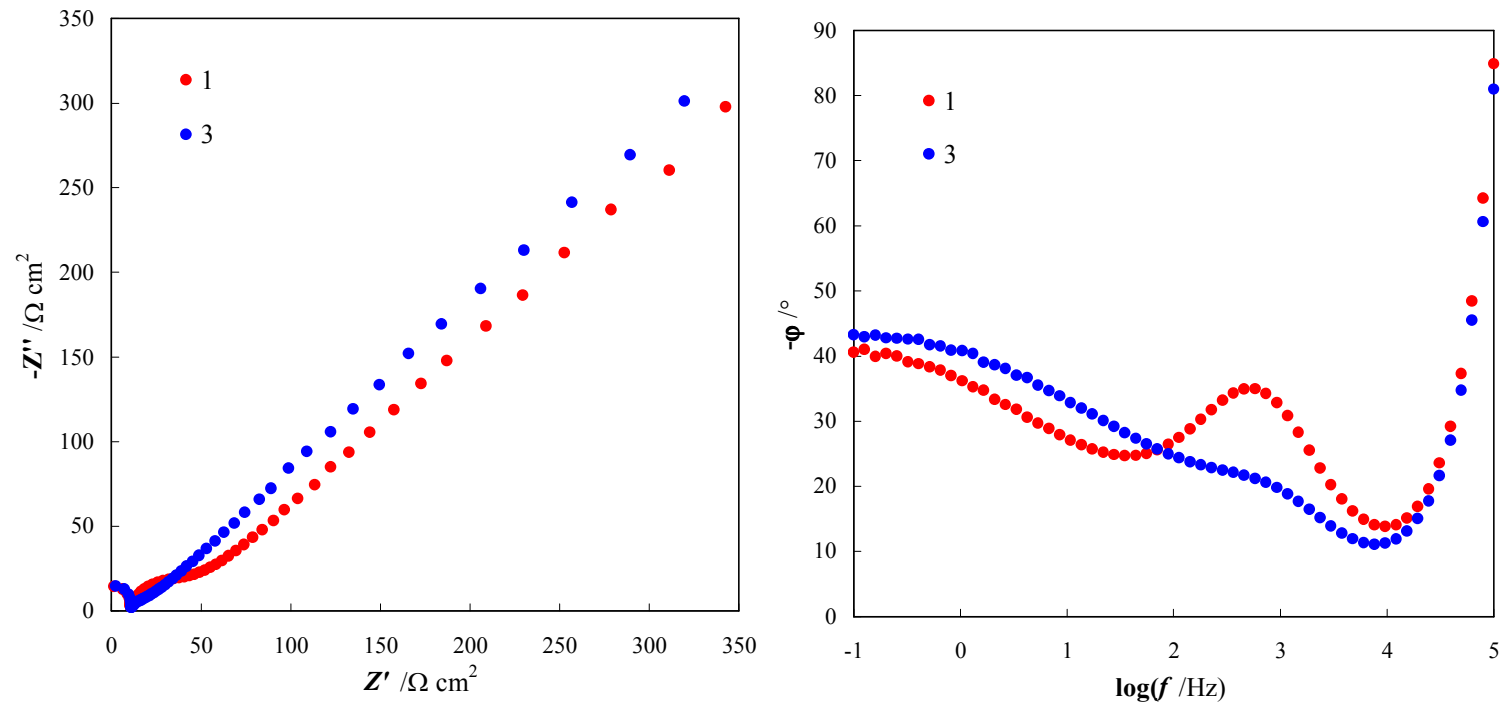

Figure S6 Nyquist diagrams and Bode phase plots for complex 1 and $\mathbf{3}$ in ACN with $\mathrm{TBAPF}_{6} 0.1$ $\mathrm{M}$ on GC electrode at their half-wave potential. Complex concentration 0.001 M. (Partially resolved arch at higher frequencies must be attributable to the geometrical capacitance of the minicell.)

\section{Effect of the counter electrode material}
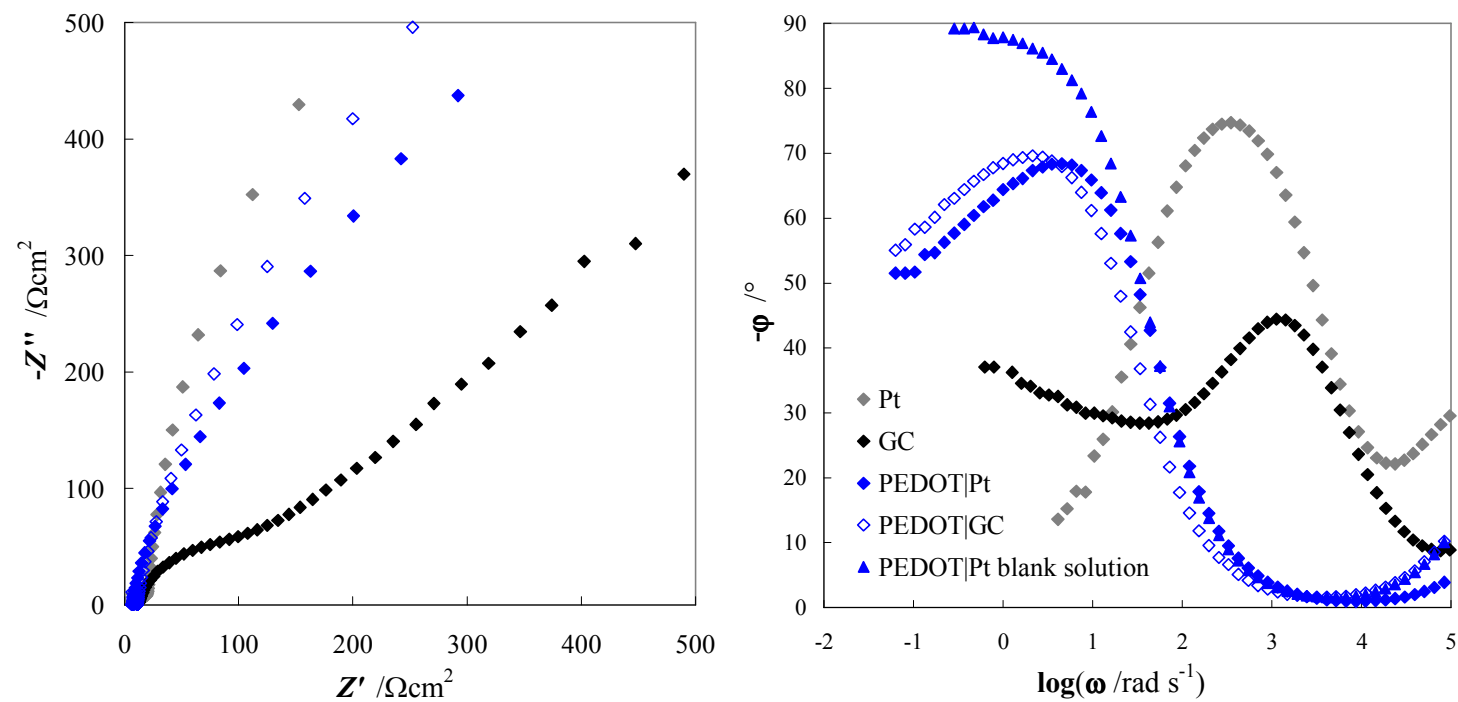

Figure S7 Magnification of the Nyquist diagrams of Figure $4 \mathrm{~b}$ in the manuscript showing the higher frequency region (left) and the corresponding Bode phase plots, showing for shake of comparison also the behavior of the PEDOT-modified electrode in a blank solution (without complex 2) showing the typical charge saturation effect at the lower frequencies. 


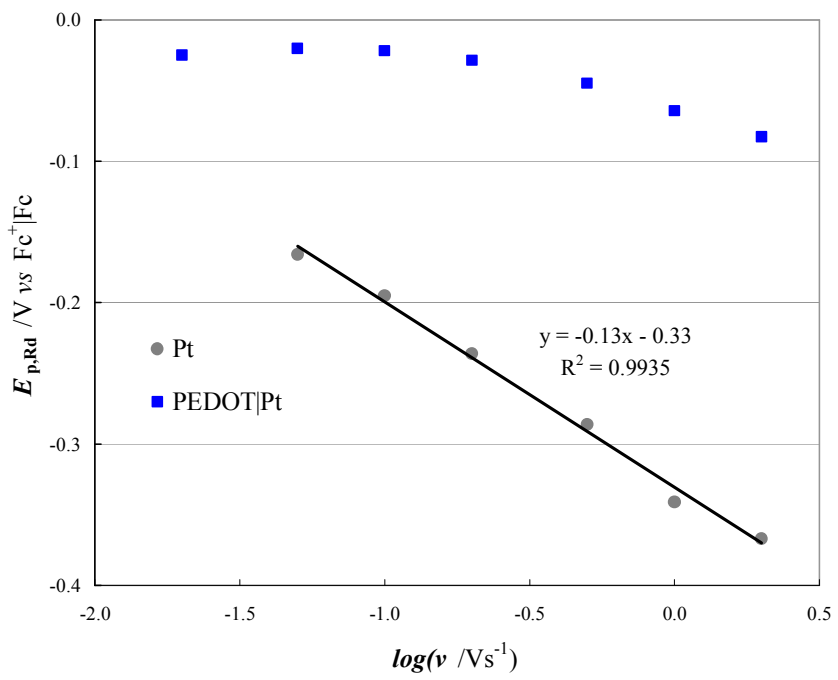

Figure S8 Variation of reduction peak potential, $E_{\mathrm{p}, \mathrm{Rd}}$, with the scan rate potential for complex $\mathbf{2}$ in ACN with $\mathrm{LiClO}_{4}$ 0.1 M on Pt and PEDOT-modified Pt electrode. Data were corrected for the ohmic drop in solution. 

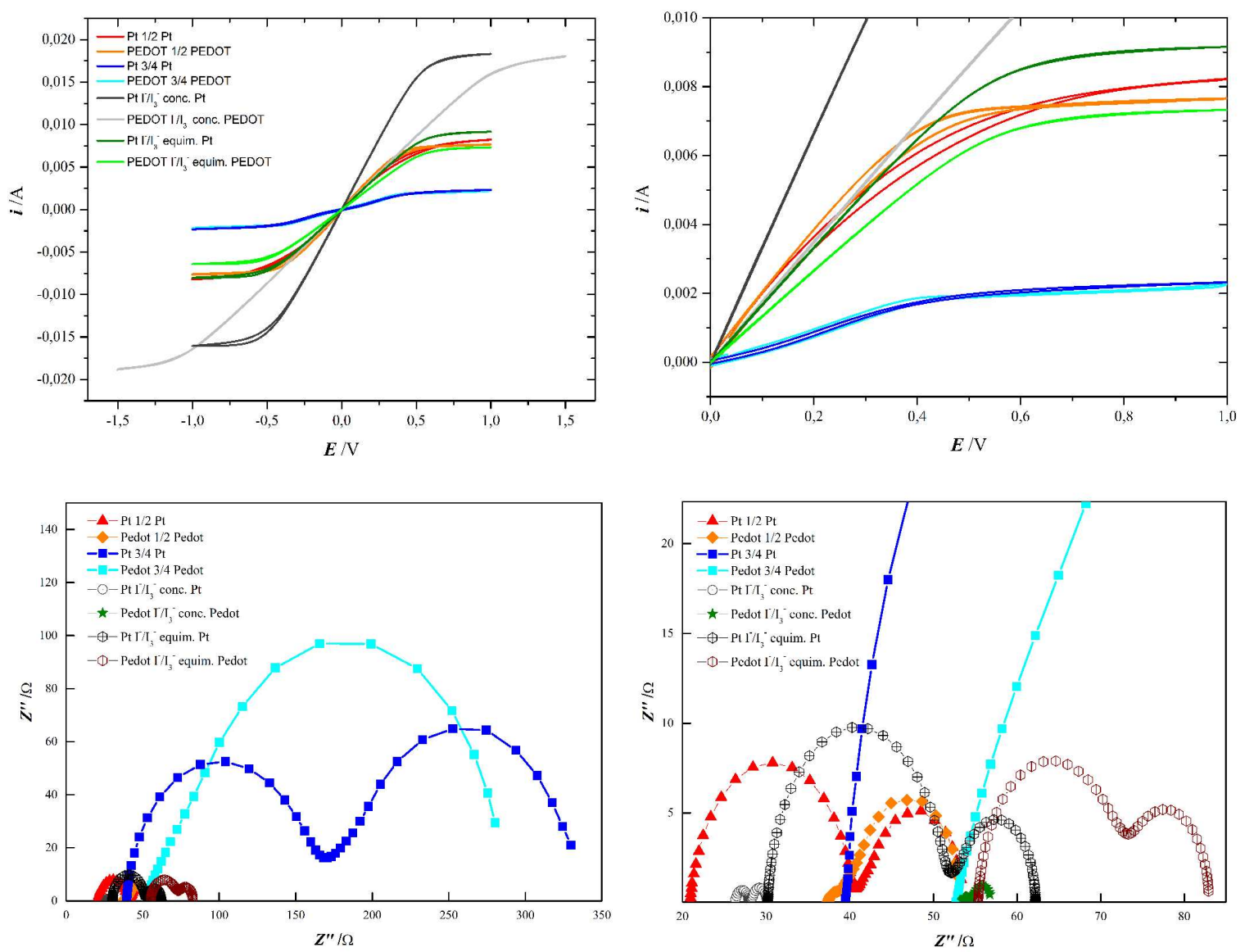

Figure S9 Polarization curves (up) and Nyquist plots (down, on the left) and their proper magnification (down, on the right) of Pt/Pt and PEDOT/PEDOT symmetric cells (effective area 1 $\mathrm{cm}^{2}$; gasket $100 \mu \mathrm{m}$ ) filled with 1/2 EL (red and orange), 3/4 EL (dark and light blue) and iodine control electrolytes. Fitted data for impedance spectra are reported in Table 1 in the manuscript. 
Transient absorption spectroscopy of $G 3$ dye

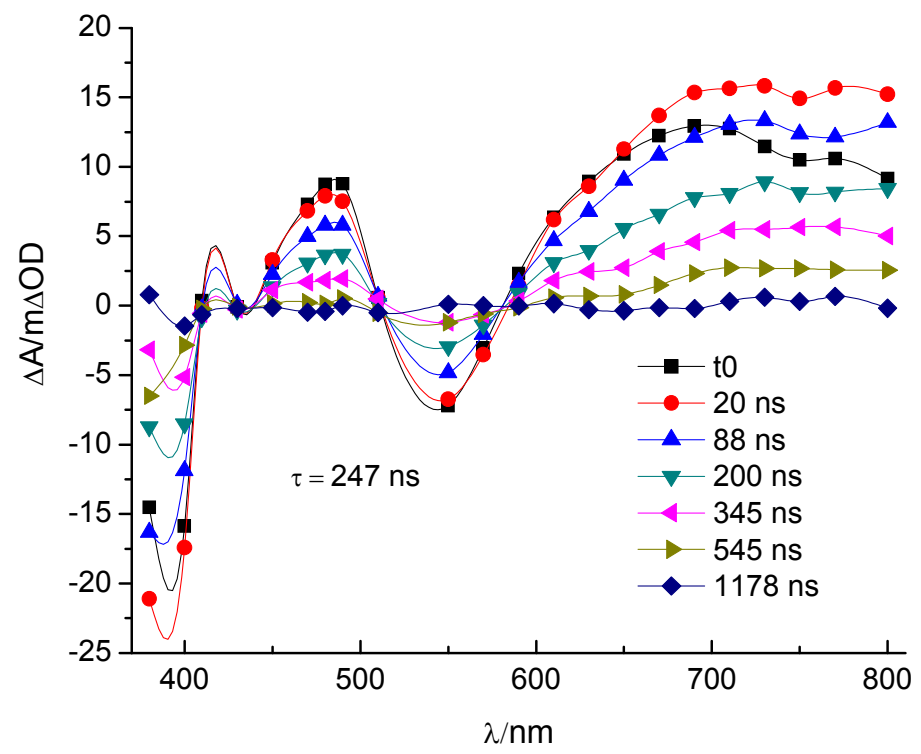

Figure S10. TA differential spectrum of G3 dye in aerated THF solution at $532 \mathrm{~nm}$ excitation. 


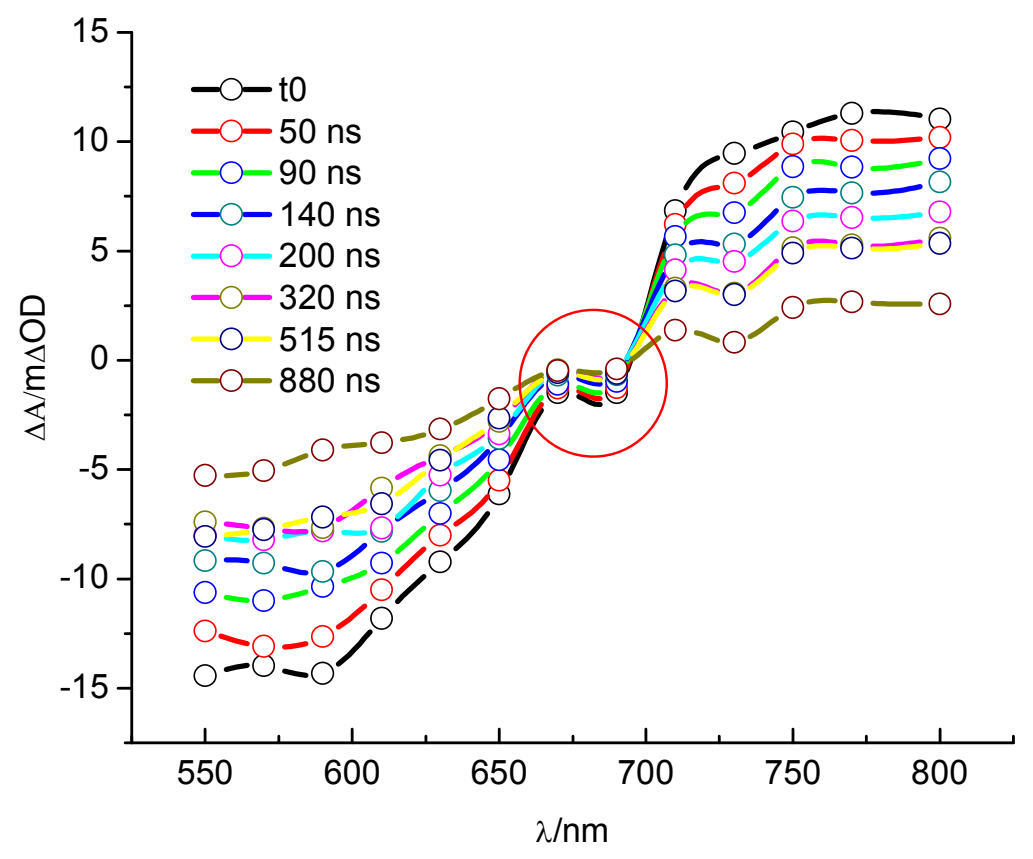

Figure S11. TA differential spectrum of $\mathbf{G 3}$ dye on $\mathrm{TiO}_{2}$ film in the presence of $\mathrm{Cu}(\mathrm{I})$ mediator $\mathbf{1}$. Due to the small extinction coefficient of $\mathrm{Cu}$ (II), the absorption of the dye radical cation in the red (e.g at $730 \mathrm{~nm}$ ) is substantially unaffected by the presence of the mediator. On the other hand, the bleaching bears the contribution of both the $\mathbf{G 3}^{+}$and of the photoinduced oxidation of $\mathrm{Cu}(\mathrm{I})$ to $\mathrm{Cu}(\mathrm{II})$. In the isosbestic region between 670 and $700 \mathrm{~nm}$ (circle), the $\mathrm{Cu}(\mathrm{I}) /(\mathrm{II})$ contribution is directly observed. 


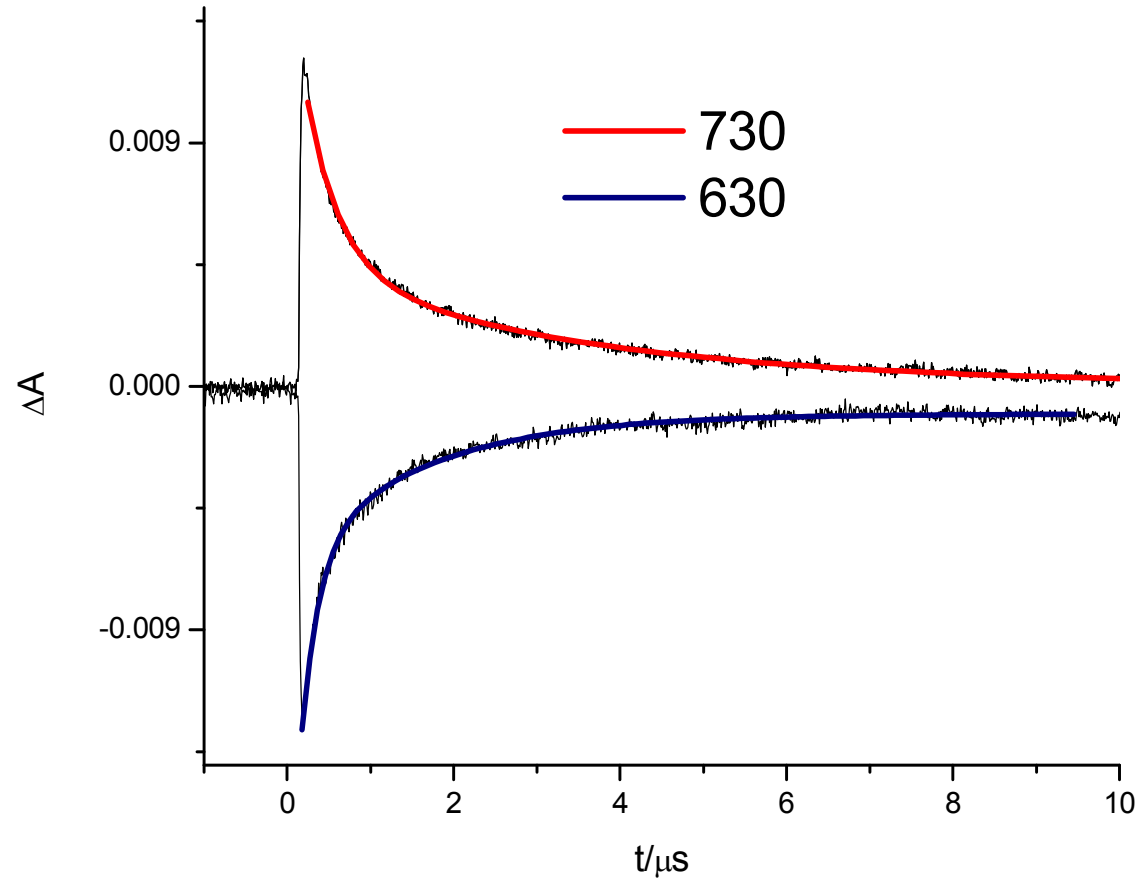

Figure S12. Kinetic traces of $\mathbf{G 3}^{+}$at 730 and $630 \mathrm{~nm}$ in a blank solution $\left(\mathrm{ACN}+\mathrm{LiClO}_{4} 0.1 \mathrm{M}\right)$. Both $730 \mathrm{~nm}$ (absorption) and $630 \mathrm{~nm}$ (bleaching) traces follow the same kinetics. 


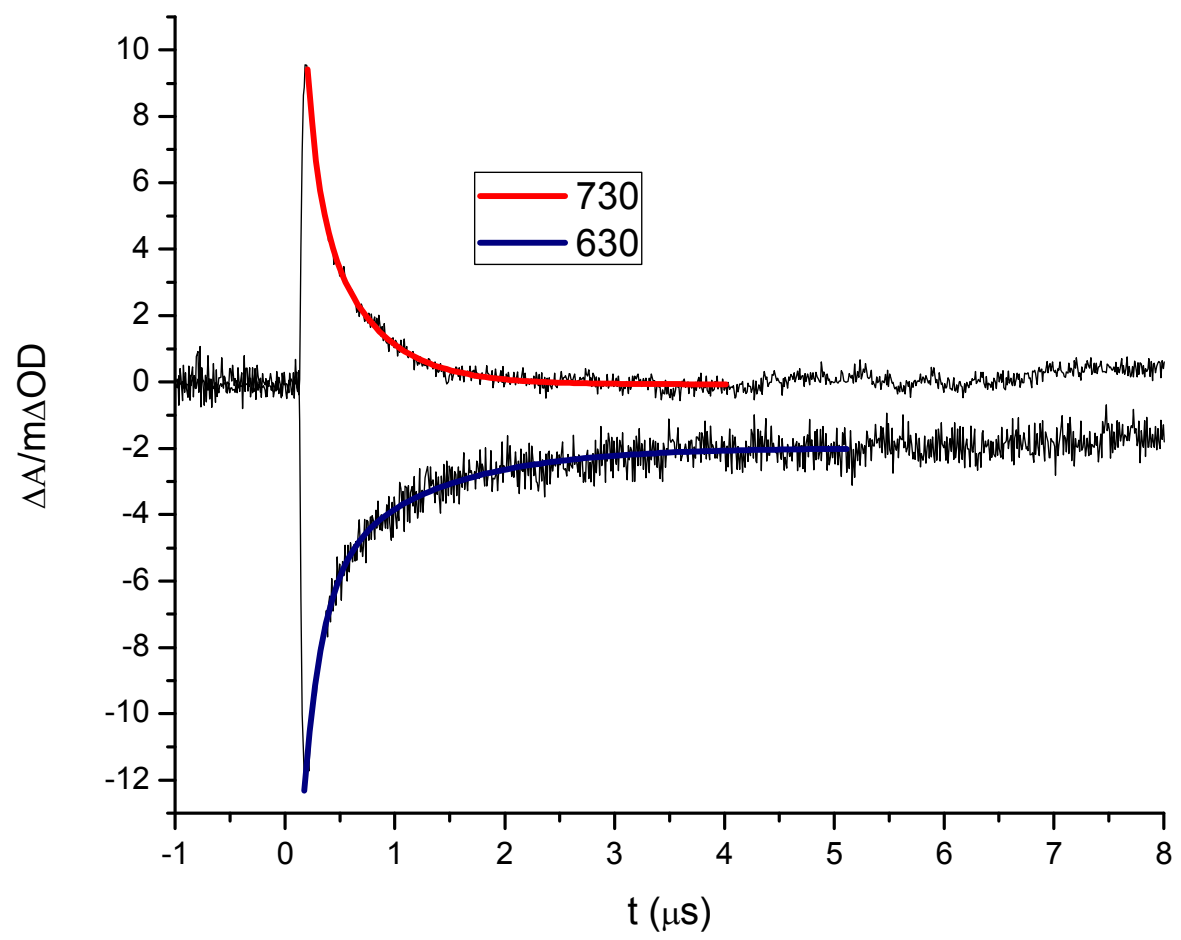

Figure S13. Kinetic traces of $\mathbf{G 3}^{+}$at 730 and $630 \mathrm{~nm}$ in the presence of $\mathrm{Cu}(\mathrm{I})$ of $\mathbf{1}$. The bleach (at $630 \mathrm{~nm}$ ) is probably affected by optical contributions arising from the formation of $\mathrm{Cu}$ (II) at the expense of $\mathrm{Cu}(\mathrm{I})$ which determines a long lived bleaching. For example, in the presence of $\mathbf{1}$, the $730 \mathrm{~nm}$ absorption, in the middle of the long wavelength plateau, where no significant optical contribution by $\mathrm{Cu}(\mathrm{I})$ is expected, is recovered completely within $1.5 \mu \mathrm{s}$, while at $630 \mathrm{~nm}$ there is a residual negative amplitude which does not recover on the time scale of the measurement. Such permanent bleaching is consistent with the consumption of $\mathrm{Cu}(\mathrm{I})$ at the interface which then recombines with a comparatively slow kinetic, occurring on the ms time scale at open circuit, according to EIS data. 
Chemical stability tests for 1/2-and 3/4-based ELs through electronic absorption spectra
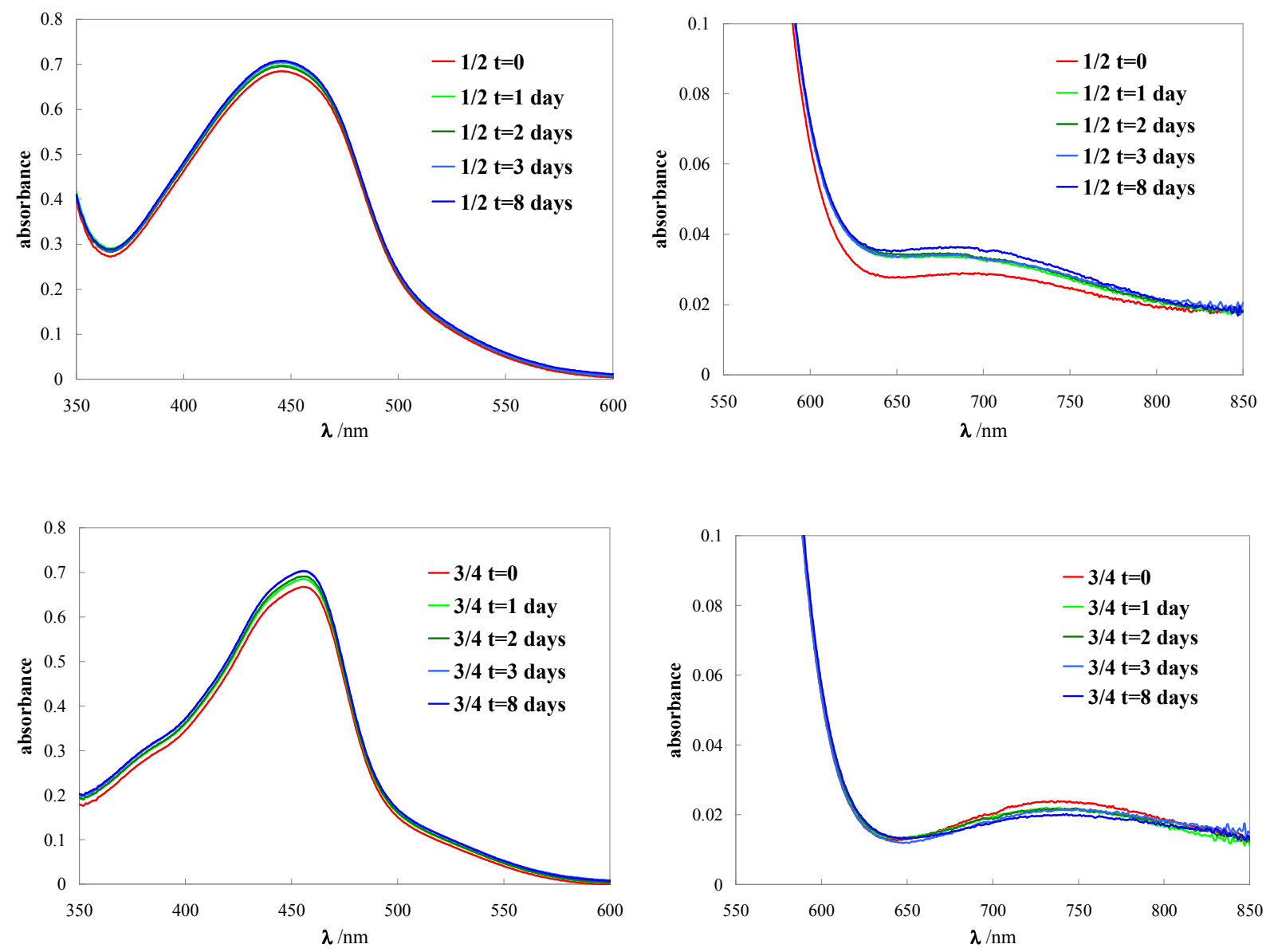

Figure S14. Electronic absorption spectra after different delay times of diluted solutions of 1/2(top) and 3/4-based mixtures (bottom) containing $0.15 \mathrm{M} \mathrm{Cu}(\mathrm{I})$ and $0.015 \mathrm{M} \mathrm{Cu}(\mathrm{II})$ species. On the left: MLCT band of $\mathrm{Cu}(\mathrm{I})$ complex; on the right: $d$ - $d$ transition for $\mathrm{Cu}(\mathrm{II})$ complex. 
Chemical stability tests for 1/2-and 3/4-based ELs monitored through mass spectra

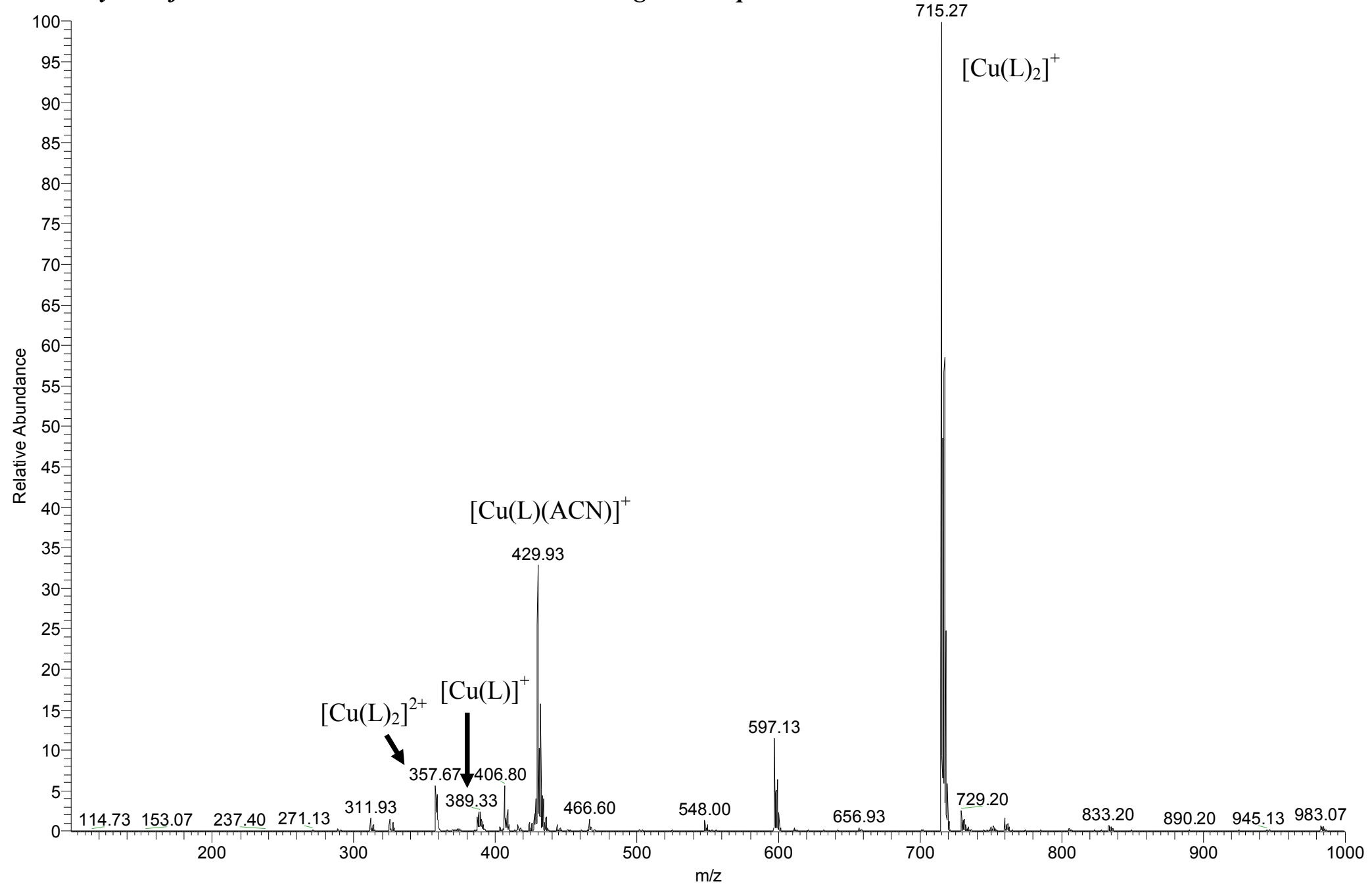

Figure S15. ESI(+) MS for the freshly prepared 1/2-based mixture of Figure S14. (Continued on next page.) 

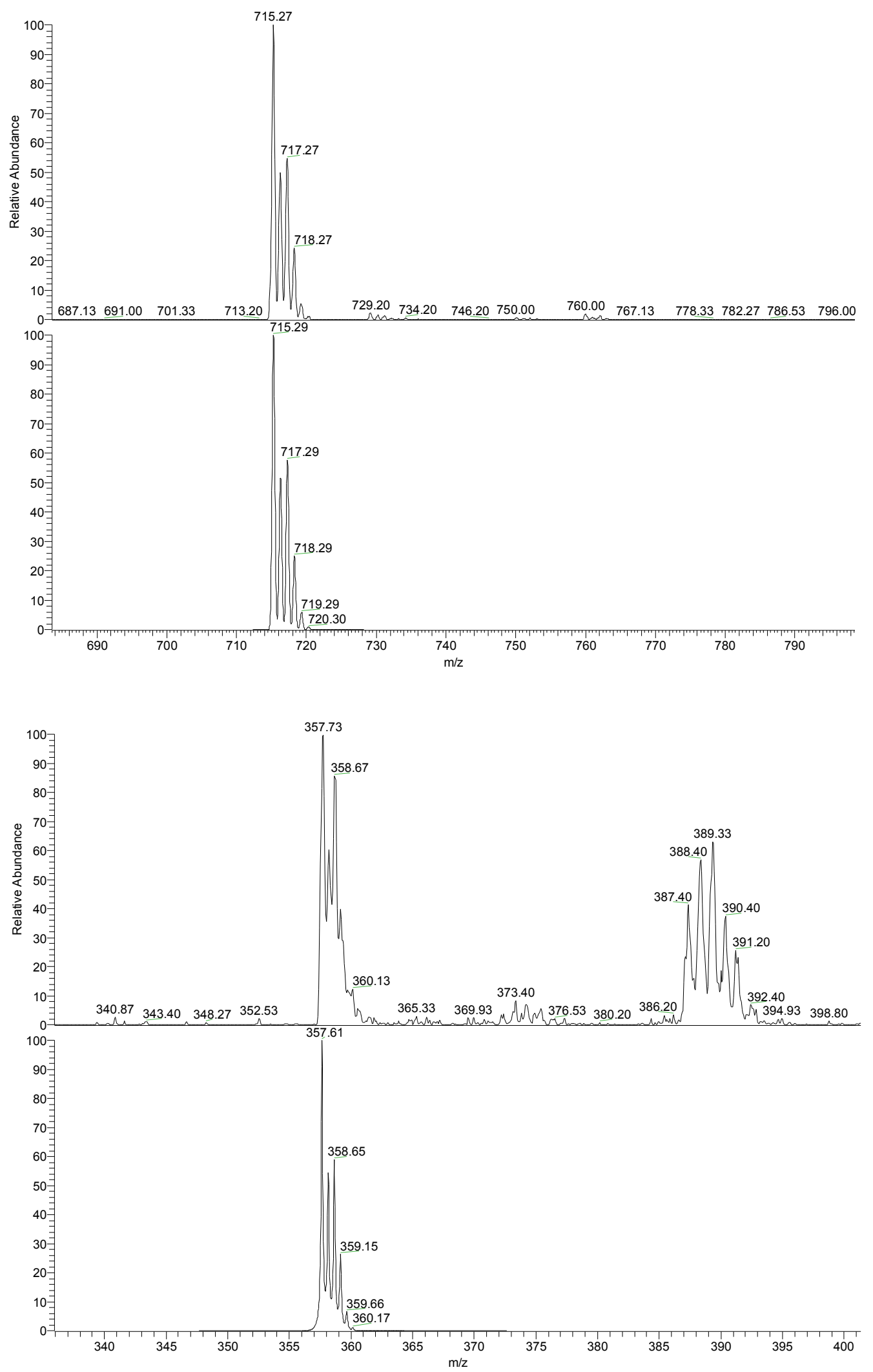

Top: magnification of the experimental (up) and theoretical (down) isotopic cluster of complex $\mathbf{1}$. Bottom: magnification of the experimental (up) and theoretical (down) isotopic cluster of complex 2. 


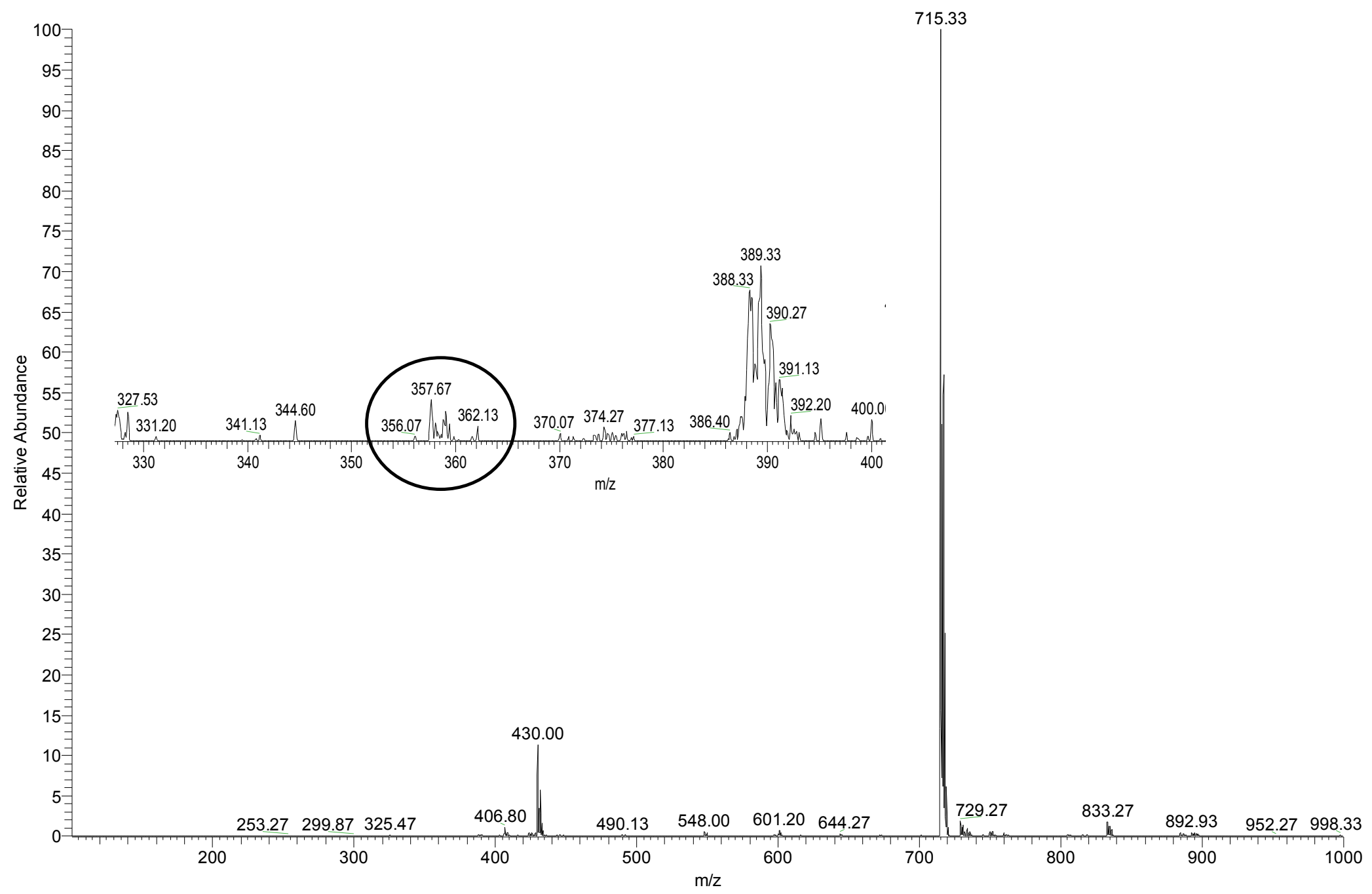

Figure S16. ESI(+) MS for the 1/2-based mixture after six days. (Inset: magnification of the region around the isotopic cluster of complex 2.) 


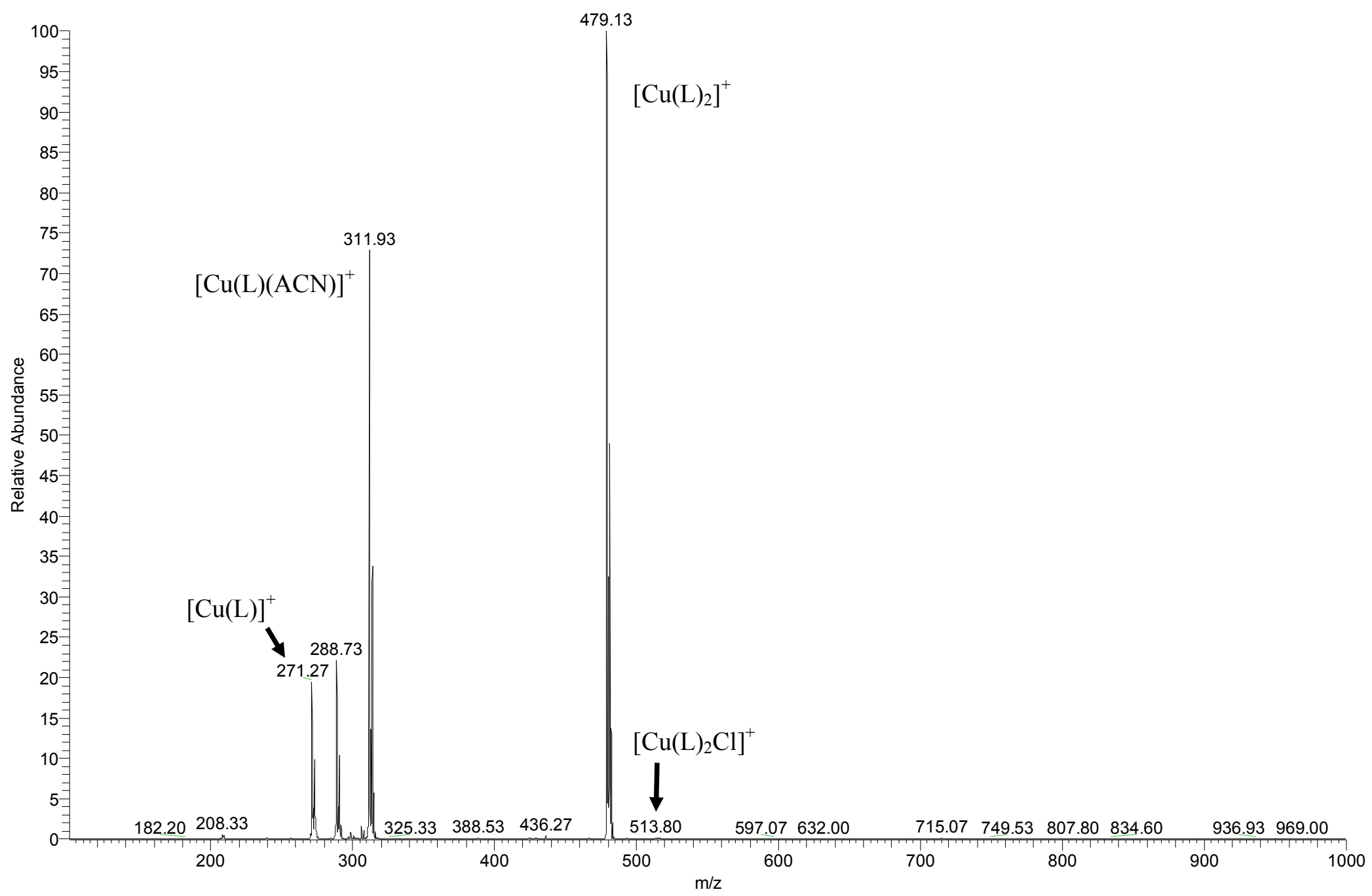

Figure S17. ESI(+) MS for the freshly prepared 3/4-based mixture of Figure S14. (Continued on next page.) 

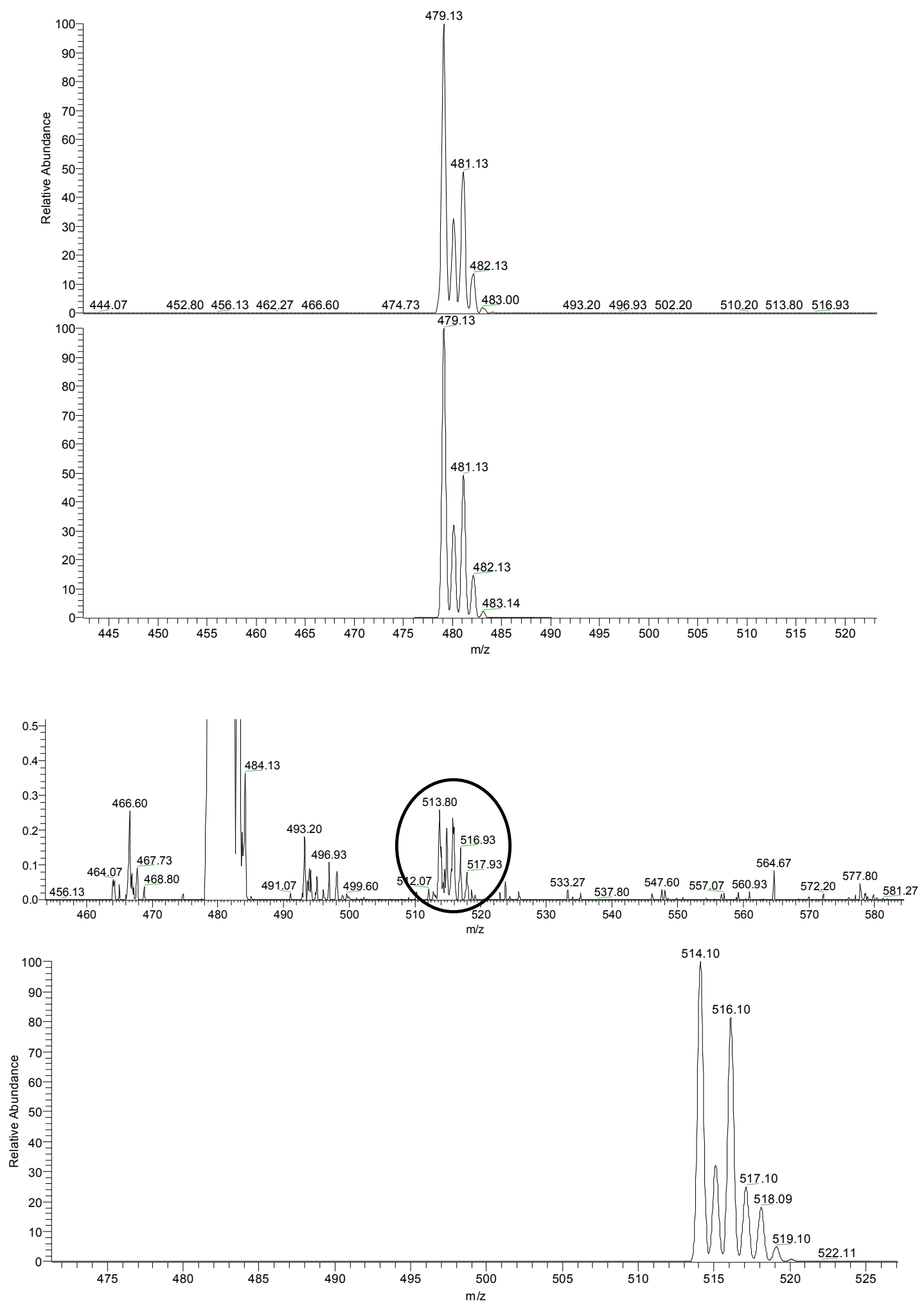

Top: magnification of the experimental (up) and theoretical (down) isotopic cluster of complex 3. Bottom: magnification of the experimental (up) and theoretical (down) isotopic cluster of complex 4. 


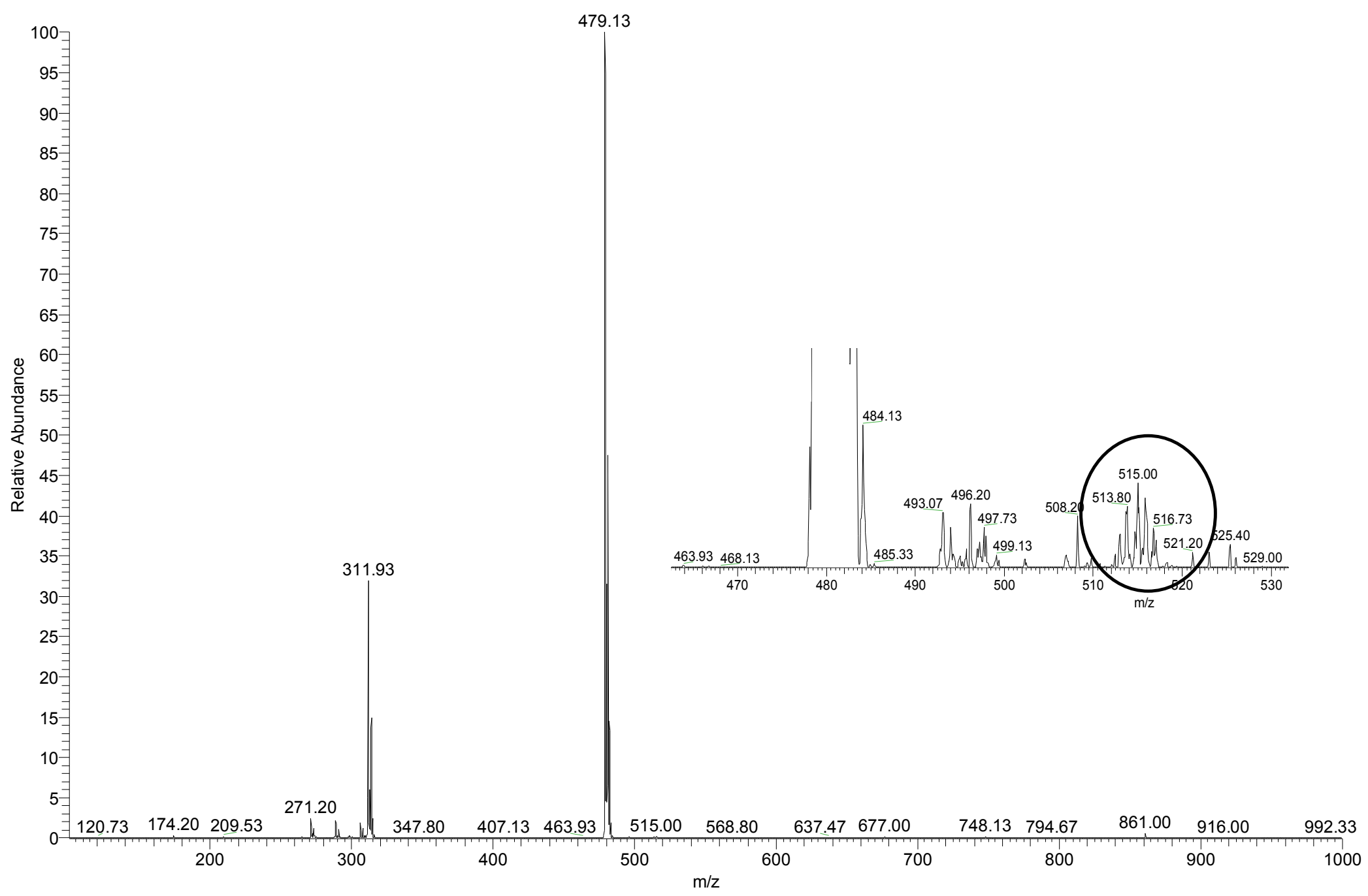

Figure S18. ESI $(+)$ MS for the 3/4-based mixture after six days. (Inset: magnification of the region around the isotopic cluster of complex 4.) 


\section{Electrochemical cyclability of 1/2- and 3/4-based ELs in symmetrical Pt/Pt cells}
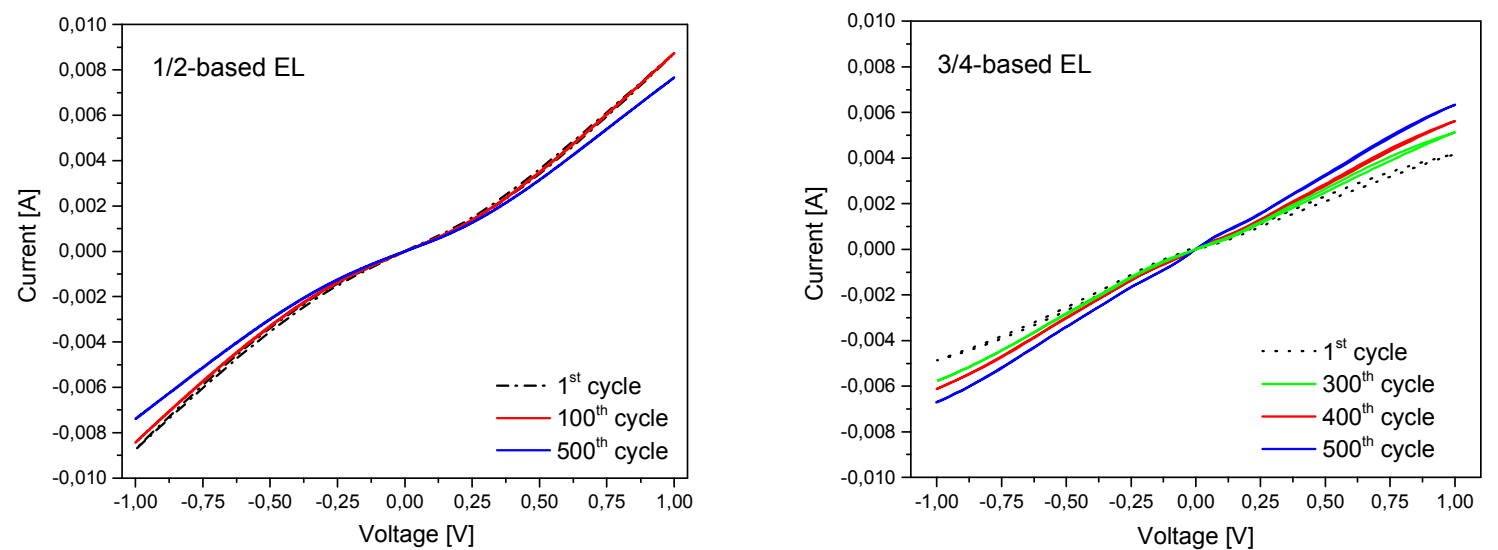

Figure S19. Polarization curves of symmetric Pt/Pt cells (active area $1 \mathrm{~cm}^{2}$, cell gap $25 \mu \mathrm{m}$ ) filled with 1/2- and 3/4-based ELs $(0.15 \mathrm{M}$ and $0.015 \mathrm{M}$ for $\mathrm{Cu}(\mathrm{I})$ and $\mathrm{Cu}(\mathrm{II})$ species, respectively; $\mathrm{LiClO}_{4} 0.1 \mathrm{M}$ and $0.25 \mathrm{M} t$-bpy in acetonitrile) detected upon different scan cycles in the range from -1 to $+1 \mathrm{~V}$ at $0.01 \mathrm{~V} \mathrm{~s}^{-1}$.

\section{DSSC tests}
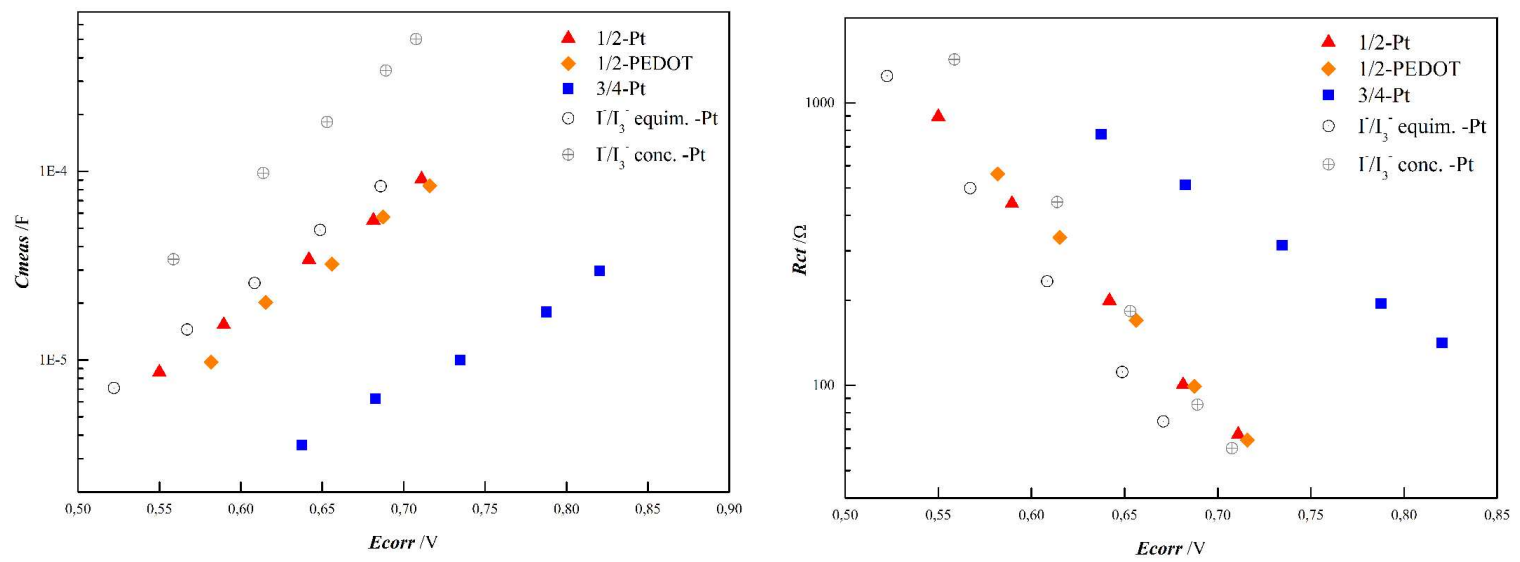

Figure S20. Potential dependence of capacitance (left) and charge transfer resistance (right) obtained from impedance spectroscopy of the solar cells with $\mathbf{1} / \mathbf{2}, \mathbf{3 / 4}$ and $\mathrm{I}^{-} / \mathbf{I}_{\mathbf{3}}{ }^{-}$electrolytes.

\section{Reference}

(1) Colombo, A.; Dragonetti, C.; Magni, M.; Roberto, D.; Demartin, F.; Caramori, S.; Bignozzi, C. A. ACS Appl. Mater. Interfaces 2014, 6, 13945-13955. 